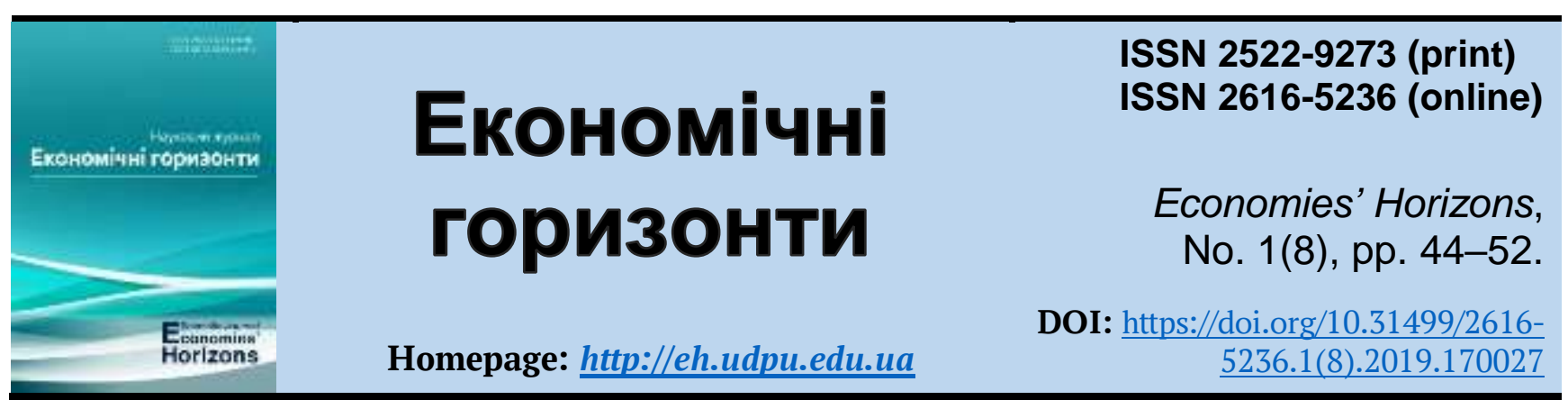

UDC 338:364

\title{
Social and economic principles of supporting people with disabilities through the perspective of professional rehabilitation
}

\author{
Nataliia M. Koliada ${ }^{1}$, Doc. Ped. Sc., Professor \\ Oksana O. Kravchenko², Doc. Ped. Sc., Associate Professor
}

Received: 11 March 2019

Accepted: 16 April 2019

\begin{abstract}
Koliada, N. M. and Kravchenko, O. O. (2019), "Social and economic principles of supporting people with disabilities through the perspective of professional rehabilitation", Economies' Horizons, no. 1(8), pp. 44-52, doi: https://doi.org/10.31499/2616$\underline{5236.1(8) .2019 .170027 .}$.
\end{abstract}

\begin{abstract}
In Ukraine there are about 3 million people with disabilities who are not able to overcome the consequences of disability without the help and special care of society. All disabled people have the right to appropriate social, psychological, medical, professional and labor rehabilitation. The purpose of the research. The purpose of the study is to find out the economic and social benefits of home work of disabled people in Ukraine. Methodology. The analysis of the current Ukrainian legislation on the promotion of the disabled people employment is carried out. The organizational and legal principles of the home work application, the substantiation of home work as a type of social and psychological rehabilitation are revealed, recommendations for conducting home work for the social support of people in difficult straits have been identified. Results. It has been determined that labor rehabilitation is a system of measures developed with regard to the inclinations, physical and mental capabilities of the person and aimed at mastering the labor skills of labor activity providing the productional adaptation, including through the creation of special or specially adapted workplaces. It should be noted that the legal data framework on social and rehabilitation services of a professional and labor direction in the current legislation of Ukraine confirms to the UN Convention on the Rights of Persons with Disabilities and the UN Convention on the Professional Recovery and Employment of Persons with Disabilities. At the same time, employment of such groups of population provides them with additional elaboration of pensions and additional financing for the development of social and rehabilitation services of the professional and labor direction. Practical meaning. It is established that labor activity, employment of disabled people is one of the most effective means of their social and psychological rehabilitation, aimed at renewal of the disabled persons' social relations and relationships, their emotional stability, active social life, integration into an open society, expansion and deepening of social contacts, renewal of professional qualities and skills, creation of favorable conditions for development and assertiveness of the person. Prospects for further research. It is necessary to define a nomenclature list of specialists in the field of professional rehabilitation and social assistance to the persons with disabilities in accordance with the
\end{abstract}

\footnotetext{
${ }^{1}$ Pavlo Tychyna Uman State Pedagogical University; Vice-Rector for Innovation Research and European Integration; Professor at the Department of Social Education and Social Work; ORCID ID: https://orcid.org/00000003-3623-6552; e-mail: koliada n@ukr.net.

${ }^{2}$ Pavlo Tychyna Uman State Pedagogical University; Dean of the Faculty of Social and Psychological Education; Professor at the Department of Social Education and Social Work; ORCID ID: https://orcid.org/0000-00029732-6546; e-mail:okskravchenko@ukr.net.
} 
Koliada N. M., Kravchenko O. O. Social and economic principles of supporting people with disabilities through the perspective of professional rehabilitation

international standards, to identify their need, to provide an organizational and methodological basis for their training and further employment.

Keywords: disabled person, employment, vocational rehabilitation, home work, social protection.

JEL Classification: H 55, I 38, J 21, J 23

Number of references: 17; number of tables: $\mathbf{0}$; number of figures: $\mathbf{1}$; number of formulas: $\mathbf{0 .}$

\title{
Соціально-економічні засади підтримки людей з інвалідністю крізь призму професійної реабілітації
}

\author{
Н. М. Коляда ${ }^{1}$, д. пед. н., професор \\ О. О. Кравченко ${ }^{2}$, д. пед. н., доцент
}

Стаття надійшла: 11.03.2019

Стаття прийнята: 16.04.2019
Koliada N. M., Kravchenko O. O. Social and economic principles of supporting people with disabilities through the perspective of professional rehabilitation. Економічні горизонти. 2019. № 1(8). C. 44-52. DOI: 10.31499/26165236.1(8).2019.170027.

Анотація. В Україні нараховується біля 3 мільйонів осіб з інвалідністю, які не в змозі подолати наслідки інвалідності без допомоги та особливої турботи з боку суспільства. Усі особи з інвалідністю мають право на відповідні види соціальної, психологічної, медичної, професійної і трудової реабілітації. Мета дослідження. Мета статті полягає у з'ясуванні економічних та соціальних переваг надомної праці людей з інвалідністю в Україні. Методологія. Здійснено аналіз чинного українського законодавства 3 питань сприяння працевлаштування людей 3 інвалідністю. Виявлено організаційно-правові засади застосування надомної праці, обгрунтування надомної праці як виду соціально-психологічної реабілітації, визначено рекомендації для провадження у вітчизняну практику надомної праці з метою соціальної підтримки людей, які опинилися у складних життєвих обставинах. Результати. Визначено, що трудова реабілітація - система заходів, розроблених з урахуванням схильностей, фізичних, розумових і психічних можливостей особи і спрямованих на оволодіння трудовими навичками забезпечення трудової діяльності та адаптацію у виробничих умовах, у тому числі шляхом створення спеціальних чи спеціально пристосованих робочих місць. Варто зауважити, що правове забезпечення даних соціально-реабілітаційних послуг професійно-трудового напрямку в сучасних Законах України відповідає Конвенції ООН про права осіб з інвалідністю, та Конвенції $\mathrm{OOH}$ про професійну реабілітацію та зайнятість осіб 3 інвалідністю. Водночас, працевлаштування згаданих груп населення забезпечує їм додатковий приробіток до пенсії $\mathrm{i}$ додаткове фінансування для розвитку соціально-реабілітаційних послуг професійно-трудового напрямку. Практичне значення. Встановлено, що трудова діяльність, працевлаштування людей 3 інвалідністю виступає одним із найефективніших засобів їх соціально-психологічної реабілітації, спрямованої на відновлення людиною 3 інвалідністю суспільних зв'язків і відносин, встановлення емоційної стабільності, активного соціального життя, інтеграцію у відкритий соціум, розширення і поглиблення соціальних контактів, відновлення професійних якостей i навичок, створення сприятливих умов для розвитку й утвердження особистості.

\footnotetext{
${ }^{1}$ Уманський державний педагогічний університет імені Павла Тичини; проректор з інноваційного розвитку та міжнародного співробітництва; професор кафедри соціальної педагогіки та соціальної роботи; iдентифікатор ORCID: https://orcid.org/0000-0003-3623-6552; e-mail: koliada_n@ukr.net.

2 Уманський державний педагогічний університет імені Павла Тичини; декан факультету соціальної та психологічної освіти; професор кафедри соціальної педагогіки та соціальної роботи; ідентифікатор ORCID: https://orcid.org/0000-0002-9732-6546; e-mail: okskravchenko@ukr.net.
} 
Перспективи подальших досліджень. Визначення номенклатурного переліку спеціалістів у сфері професійної реабілітації та соціальної допомоги особам 3 інвалідністю відповідно до міжнародних стандартів, виявлення потреби в них, забезпечення організаційно-методичної бази для їх навчання та наступного працевлаштування $\epsilon$ перспективами подальших досліджень авторів.

Ключові слова: людина 3 інвалідністю, працевлаштування, професійна реабілітація, надомна праця, соціальний захист.

Кількість джерел: 17; кількість таблиць: 0; кількість рисунків: 1; кількість формул: 0.

\section{Introduction.}

In Ukraine there are about 3 million of people with disabilities who are not able to overcome the consequences of disability without the help and special care of society. All disabled people have the right to appropriate social, psychological, medical, professional and labor rehabilitation

Citizens with disabilities are among all the social groups of any society. These are people with such health problems as lesions of the musculoskeletal system and the central and peripheral nervous system; mental illness and mental retardation; lesions of the organs of hearing and eyesight; lesions of internal organs; cancerous diseases. The number of people with special needs is steadily increasing, although the causes and consequences of disability may be different: due to different social and economic circumstances, and the different welfare level of the citizens. Today we can talk about the global nature of the problem of disability - in the whole world about every tenth person has limited capacities (650 million people), among them nearly 470 million people of working age.

\section{Problem analysis.}

Rehabilitation and social and psychological measures aimed at their vocational training, labor and everyday life begin already since the limitation of the vital functions and health of the organism functioning, which led to the disability and last until the certain involvement of the disabled person in the labor process and society life.

\section{Literature review.}

For the practical social and vocational rehabilitation of the disabled people, the solution of their employment issues is the scientific works of the following Ukrainian scientists.

O. Globa (2015) researched the issue of self-realization of persons with disabilities in the process of their labor rehabilitation, emphasizing that the implementation of state and regional programs of social protection in Ukraine is impossible without the resuscitation and development of a modern system of vocational education (including for disabled people) for competitive professions and specialties.

The international standards of the legal possibilities of the disabled people on the way of their employment are analyzed, the present state of this problem in the domestic legislation and the ways of possible implementation of international rules are researched in the scientific work of A. Boiko (2013).

H. Dzhulai (2011) devoted her study to the peculiarities of the legal regulation of the job of the home based workers at the present stage of the Ukrainian society development.

The scientific work of I. Verkhovod (2007) is devoted to the improvement of theoretical and methodological principles for the creation of the integral system of social and professional rehabilitation of the disabled people and the development of scientific and practical recommendations for improving the mechanism of its functioning.

The scientific work of A. Shevtsov and I. Chuhrii (2017) is important from the scientific and practical point of view.

I. Teriukhanova (2007) conducted the analysis of the existing system of vocational rehabilitation of disabled people in Ukraine through vocational education, vocational 
training at the State Employment Service and centers for the professional rehabilitation of the disabled, and developed the directions of increasing the efficiency of this system as a part of the general system of rehabilitation, an active component of employment policies and increasing the competitiveness of people with disabilities in the labor market to accelerate the integration processes of this social group.

The main organizational and methodical approaches to the development of the homebased job organization as one of the best ways to attract people with disabilities to the process of work is substantiated by $\mathrm{H}$. Havriushenko (2008).

\section{Methods.}

A number of research methods have been used in this article. First, we turned to the analysis of the current Ukrainian legislation on the promotion of the employment of people with disabilities. Secondly, during the analysis of the employment status of people with disabilities in Ukraine, the identification of organizational and legal principles for the use of home work, the substantiation of home work as a form of social and psychological rehabilitation, the recommendations for home work implementation for the social support of people in difficult straits.

\section{Research objectives.}

Purpose and objectives - to identify the economic and social benefits of home work for people with disabilities in Ukraine.

\section{Results and discussions.}

Professional and labor rehabilitation of persons with disabilities are regulated by the following Laws of Ukraine in which the legal mechanisms for the provision of these services are established, namely:

1) The Law of Ukraine "On Social Services" (The Verkhovna Rada of Ukraine, 2019):

"Employment services are the search for suitable job, employment assistance and social support for the employed person";

2) The Law of Ukraine "On Rehabilitation of the Disabled in Ukraine" (The
Verkhovna Rada of Ukraine, 2005):

"Professional rehabilitation is a system of measures aimed at preparing a person for professional activity, renewal or gaining of professional ability through the adaptation, preadaptation, training, reskilling or job retraining with possible further employment and necessary social support, taking into account personal inclinations and wishes of a person";

"Labor rehabilitation is a system of measures developed with regard to the inclinations, physical and mental capabilities of the person and aimed at mastering the labor skills of labor activity providing and productional adaptation, including through the creation of special or specially adapted workplaces";

"Occupational orientation" is a scientifically substantiated system of forms, methods, means of influencing the person for the promotion of his/her professional self-determination on the basis of the state of health, educational and professional qualification levels, interests, abilities, individual, psychophysiological features and needs of the branches of the economy";

"Occupational selection is a scientifically substantiated system of determining the degree of suitability of a person to a specific profession, specialty (workplace, position) in accordance with regulatory requirements established by law";

"Occupational adaptation is a system of measures aimed at ensuring the successful professional formation of a worker, the formation of his/her professional qualities, values, needs to active and creative work";

"Workplace of a disabled person is a place or a production site of permanent or temporary location of a person in the process of labor activity at the enterprises, institutions and organizations";

"Special workplace of a disabled person is a separate work place or a part of a production space that requires additional measures for the organization of work of a person, taking into account his/her individual functional capabilities caused by the disability, by adapting 
the basic and additional equipment, technical equipment, etc.";

"Individual rehabilitation program is a complex of optimal types, forms, volumes, terms of rehabilitation measures with a definition of the order and place of their conduct, aimed at the renewal and compensation of the disordered or lost functions of the organism and the ability of a specific person to perform activities identified in the recommendations of the medical and social expert commission" (The Verkhovna Rada of Ukraine, 2019).

The financial provision of professional and labor rehabilitation of persons with disabilities is regulated by the Law of Ukraine "On the Fundamentals of Social Security of the Disabled in Ukraine”, in particular Articles 12, 14/1, 14/2, 14/3, 15, 16 of Chapter III "Social Organizations of Persons with Disabilities" and the Regulations on State Fund for Social Protection of Persons with Disabilities (The Verkhovna Rada of Ukraine, 1991).

$80 \%$ of people with disabilities are active and able to work, but because of the public space inaccessibility they can not fully exercise their right to work. And this is a big problem today. Therefore, it is very important to finally start to create a real barrier-free space in Ukraine (Teriukhanova, 2007, p. 34). And this is one of the main tasks of the Ministry of Regional Development.

The new State Constitution Rules on Inclusion contain about 100 qualitative changes for the mandatory creation of accessible space for all physically challenged groups. Also the obligatory part of jobs for people with disabilities is prescribed when designing enterprises, institutions and organizations. And of course the buildings of these institutions should also have a real barrier-free space from the outside and inside. It is obligatory. This will facilitate: employment of disabled people and their further professional development; ensuring their right to work and adaptation in society. Workplaces must be safe for health, well-organized, located not more than $50 \mathrm{~m}$ from the toilets, drinking water, heating and food. If a specialized workplace for a disabled person is projected, then it should include a set of furniture, equipment and auxiliary devices adapted for a particular type of disability. The area of one workplace in the office and administrative premises for a disabled person in a wheelchair - not less than 5,65 square meters.

The accessible parking spaces and entrances to buildings; accessible elevators and other lifting devices; available security zones and other accessibility elements should also be provided and identified by the international accessibility symbols. Information and alarm system should have visual, sound and tactile information, identification of premises inside buildings should be duplicated with tactile signs and placed next to the door on the side of the door handles.

However, it should be noted that there are always such disabled persons, whose employment, because of severe health restrictions and, consequently, the high cost of creating the necessary working conditions for them, will be impossible or extremely difficult to organize even in specialized workplaces. For such people (that is, for persons having the Ist and the IId groups of disability, whose share in 2005 was 14.2 and $46.7 \%$ from the total quantity of the disabled people), the most optimal form of employment would be a home work (Havriushenko, 2008, p. 71).

Article 18 of the Law of Ukraine "On the Fundamentals of Social Security of the Disabled in Ukraine" (No. 875-XII of March 21, 1991) provides for the possibility of home work for the disabled people, in particular, it states that the state employment service promotes employment with the condition of performing work at home for the disabled people unable to work at enterprises. The ILO Home Work Convention No. 177 (1996a) and the Recommendation No. 184 (1996b) on Home Work define the term "home work" as a work performed by a person at his place of residence or in other premises chosen, but not in the premises of the employer; for a consideration; in order to produce goods or services in accordance with the instructions of the employer. Recommendation No. 184 clarifies that the 
term "employer" means a natural or legal person who provides home work in favor of his enterprise, which implies that individual entrepreneurs can use home work (International Labour Organization, 1996b).

According to clause 1 of the Regulations on working conditions of homeworkers, approved by the decision of the State Committee of Labor of the USSR of September 29, 1981, No. 275/17-99 (hereinafter - Regulation No. 275), homeworkers are persons who have concluded an employment contract with the enterprise to perform work at home personally from materials and using the tools and given by the employer or purchased at his expense, as well as from his own materials and using personal mechanisms and tools with the permission of the management (State Committee of Labor of the USSR, 1981).

Fig. 1 shows the classification of persons who are given the preferential right of home work.

\section{PERSONS WHO ARE GIVEN THE PREFERENTIAL RIGHT OF HOME WORK}

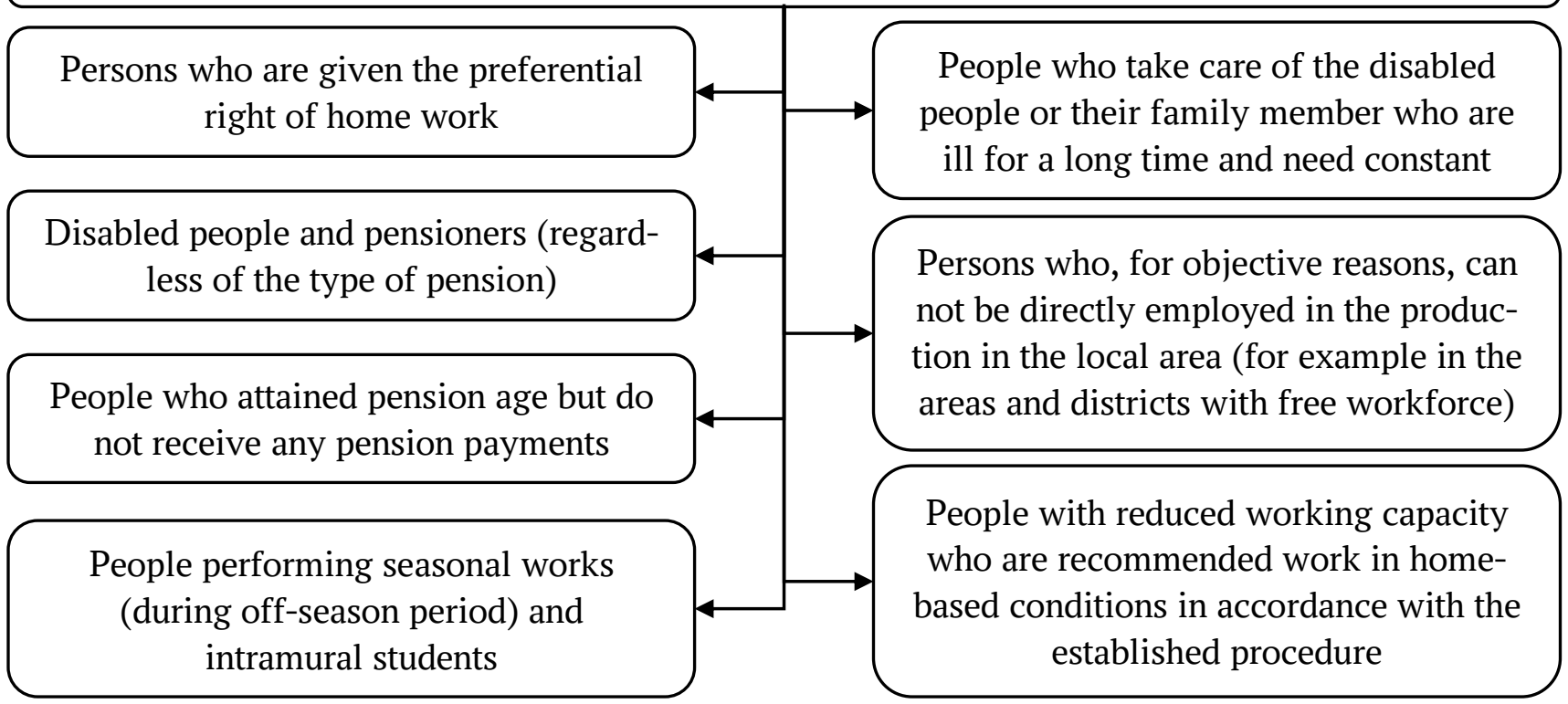

Fig. 1. Classification of persons who are given the preferential right of home work

Source: classified by the authors.

Homeworkers subject to the labor legislation, as well as to the collective agreements. The work of homeworkers is usually directed at the production of consumer goods and the provision of certain types of services. The corporate management can also use the work of homeworkers for the manufacture of other types of products (works), if by nature and technology of production it is possible in home-based conditions and economically feasible. Recently, home work is used in various areas of activity. Previously the homeworkers mainly worked as dispatchers, supply agents, designers, editors and other employees of similar professions, nowadays more and more employees attract skilled workforce, such as engineers, technicians, researchers, IT specialists, creative workers (journalists, teachers), to home work.

The homeworker's place of work may be his apartment or other suitable premises that belong to him, including not at the location (legal address) of the enterprise, that is, in another locality (settlement).

Apartment of a homeworker must meet certain requirements. In particular, in clause 9 of the Regulation No. 275 it is stated that the organization of labor processes at home is permissible only for persons who have proper living conditions.

The living conditions of the homeworker are examined by the employer's representative 
with the participation of the representative of the trade union body, and, if necessary, the representatives of the sanitary and/or fire supervision authorities (Dzhulai, 2011, p. 101). If there is no trade union body at the enterprise, it is expedient to involve the members of the representative body of the labor collective, for example, the work collective council, before the examination. During the examination it is necessary to pay attention to whether the work done by the homeworker will not create inconveniences to the neighbors, since in accordance with the clause 12 of the Regulation number 275 such kinds of work are prohibited for the homeworkers. The results of the examination are filed under the act.

In accordance with the requirements of the Labor Code, an employment agreement with employees is usually concluded in writing. The corresponding rule is also stipulated by the Regulation No. 275 for the homeworkers. At the same time, the labor legislation does not specify any legal consequences for the parties of the agreement in case of non-compliance with its written form, including the agreement cancellation.

The Ministry of Social Policy in a letter dated November 25, 2015, No. 692/13/133-15 clarified that an employment agreement with homeworkers is concluded, as a rule, in writing.

Since the homeworkers distribute working time at their discretion and labor compensation is accrued for the actual work done, there is no time sheet for such workers.

Upon agreement of the parties, the homeworker can be reimbursed for expenses incurred for the company at home (electricity, water, etc.). This should be resolved when concluding an employment agreement.

There is no clear definition of the term "home work" in Ukrainian labor legislation. Part 8 of the Article 179 of the Labor Code (1971) of Ukraine stipulates that a woman or persons mentioned in part seven of this article (the father of a child, a woman, grandparent or other relatives who are actually caring for the child) during their period of their childcare leave, at their request, can ask for the part-time employment or work at home (The Verkhovna Rada of Ukraine, 2005).

At the same time, labor legislation does not prohibit to conclude, both by hiring, and later, the Remote Employment Agreement, subject to the provisions of the current legislation.

It should be noted that point 1.1 of the Methodological Recommendations on the Workplace Definition (1995), approved by the Minutes of the Ministry of Labor of Ukraine dated 21.06.95 No. 4, provides that homeworkers are workers whose working place coincides geographically with their place of residence. Their workplaces are mainly equipped with the tools, instruments and small machines.

The work of homeworkers is regulated by the Regulations on labor conditions of homeworkers, approved by the decision of the State Committee of Labor of the USSR of September 29, 1981, No. 275/17-99, taking into account that its rules, which contradict the legislation of Ukraine, do not apply, and also the collective and labor agreements. They are subject to the rules of the Labor Code of Ukraine.

According to the ILO Home Work Convention No. 177 of the year 1996, the term “homework' refers to the work that a person performs: at his place of residence or in other premises at his option, but not in the premises of the employer; for a consideration; in order to produce goods or services, in accordance with the instructions of the employer (International Labour Organization, 1996a).

The employment agreement with homeworkers is usually concluded in writing. It should contain both the main and additional terms that determine the mutual obligations of the parties. Hiring a homeworker is made by order (commission) of the employer. This is a kind of labor homework agreement, as a person's own work, using the materials, tools and means of labor, allocated by the enterprise or purchased at its expense.

The employer may allow homeworkers to manufacture products for the enterprise 
from their own materials and using personal tools. The work of homeworkers should be directed, as a rule, to the production of consumer goods and the provision of certain types of services. An enterprise may use the work of homeworkers also for the production (execution) of other types of work, if by nature and technology of production it is possible in home-based conditions and is economically feasible.

Organization of labor processes at home is allowed only for persons who have the appropriate living conditions, as well as practical skills for the performance of these works. The examination of living conditions of citizens willing to work at home is carried out by representatives of the employer with the participation of representatives of the trade union body, and, where appropriate, representatives of sanitary and fire supervision.

It is forbidden to entrust homeworkers to perform such types of work, which create inconveniences for the neighbors.

The labor compensation of homeworkers is carried out at the piece-work rate for the works actually completed or for the manufactured products, which meets the established requirements for its quality. Upon agreement of the parties, the homeworker can be reimbursed for expenses incurred for the company at home (electricity, water, etc.).

Taking into account the above mentioned, in our opinion, computers, printer, modem and office furniture owned by an employee with whom an employment agreement for home work has been concluded can be included to his own tools and mechanisms. However, this should be resolved by concluding an employment home work agreement.

It should also be noted that since the homeworkers distribute working time at their discretion and labor compensation is accrued for the actual work done, there is no time sheet for such workers. At the same time, the employer is required to keep an account of all homeworkers, whom he provides work, and keep a register of work tasks assigned to the homeworker, indicating the time allocated for the tasks; tariff rates of wages; costs for the home work performance (electricity, water, etc.).

\section{Conclusions.}

It is established that labor activity, employment of disabled people is one of the most effective means of their social and psychological rehabilitation, aimed at renewal of the disabled persons' social relations and relationships, their emotional stability, active social life, integration into an open society, expansion and deepening of social contacts, renewal of professional qualities and skills, creation of favorable conditions for development and assertiveness of the person. It should be noted that the legal data framework on social and rehabilitation services of a professional and labor direction in the current legislation of Ukraine confirms to the UN Convention on the Rights of Persons with Disabilities and the UN Convention on the Professional Recovery and Employment of Persons with Disabilities. At the same time, employment of such groups of population provides them with additional elaboration of pensions and additional financing for the development of social and rehabilitation services of the professional and labor

Training of the appropriate personnel in this situation is of great importance. It is necessary to define a nomenclature list of specialists in the field of professional rehabilitation and social assistance to the persons with disabilities in accordance with the international standards, to identify their need, to provide an organizational and methodological basis for their training and further employment. It is necessary to create conditions for changing negative stereotypes and attitudes towards disabled people in Ukrainian society, based on the achievement of social solidarity and social justice, and to promote the establishment of a general principle: "Look at me as an equal". 


\section{References}

Boiko, A. K. (2013), “Concerning employment of disabled persons in Ukraine”, Zbirnyk naukovykh prats Kharkivskoho natsionalnoho pedahohichnoho universytetu imeni H. S. Skovorody “Pravo”, vol. 20, pp. 48-51.

Dzhulai, H. H. (2011), “Legal aspects of labor regulation for homeworkers”, Stanovlennia ta rozvytok pravovoi derzhavy: problemy teorii ta praktyky [Formation and development of the rule of law: problems of theory and practice], Materialy naukovo-praktychnoi konferentsii [Materials of the scientific-practical conference], Mykolayiv, Ukraine, November, 22, 2011, pp. 97-101.

Globa, O. P. (2015), "Pedagogical conditions for ensuring of occupational rehabilitation of persons with disabilities”, Naukovyi chasopys Natsionalnoho pedahohichnoho universytetu imeni M. P. Drahomanova. Seriia 19. Korektsiina pedahohika ta spetsialna psykholohiia, vol. 30, pp. 41-47.

Havriushenko, H. V. (2008), “The "Homework's" (outwork) form of organization of work - the way to rise of employment level of disabled people”, Demohrafiia ta sotsialna ekonomika, no. 2, pp. 170-178.

International Labour Organization (1996a), Home Work Convention no. 177, available at: https://zakon.rada.gov.ua/laws/show/993 327?lang=en (Accessed 6 March 2019).

International Labour Organization (1996b), Recommendation for Home Work no. 184, available at: https://zakon.rada.gov.ua/laws/show/993 100?lang=en (Accessed 6 March 2019).

Ministry of Labor of Ukraine (1995), Methodological Recommendations on the Workplace Definition, available at: https://zakon.rada.gov.ua/rada/show/v0004205-95?lang=en (Accessed 6 March 2019).

Ministry of Social Policy (2015), Letter "On the Work of Homeworkers", available at: https://www.profiwins.com.ua/uk/letters-and-orders/ministry-of-labor-and-social-policy/13524-692s$\underline{15 . h t m l}$ (Accessed 6 March 2019).

Shevtsov, A. and Chuhrii, I. (2017), "Psychological mechanisms of social adaptation of young people with disabilities”, American Journal of Fundamental, Applied \& Experimental Research, no. 3 (6), pp. 6-14.

State Committee of Labor of the USSR (1981), Resolution "On approval of the "Regulations on working conditions of homeworkers”, available at: https://zakon.rada.gov.ua/laws/show/v0275400-81?lang=en (Accessed 6 March 2019).

Teriukhanova, I. M. (2007), "Professional rehabilitation of the disabled as an effective means of their integration into society”, Demohrafiia ta sotsialna ekonomika, no. 1, pp. 142-150.

The Verkhovna Rada of the Ukrainian Soviet Socialist Republic (1971), The Labor Code of Ukraine, available at: https://zakon.rada.gov.ua/laws/show/322-08?lang=en (Accessed 6 March 2019).

The Verkhovna Rada of Ukraine (1991), The Law of Ukraine "On the Fundamentals of Social Security of the Disabled in Ukraine”, available at: https://zakon.rada.gov.ua/laws/show/875-12?lang=en (Accessed 6 March 2019).

The Verkhovna Rada of Ukraine (2005), The Law of Ukraine “On Rehabilitation of the Disabled in Ukraine”, available at: https://zakon.rada.gov.ua/laws/anot/en/2961-15 (Accessed 6 March 2019).

The Verkhovna Rada of Ukraine (2012), The Law of Ukraine “On Employment of Population”, available at: https://zakon.rada.gov.ua/laws/show/5067-17?lang=en (Accessed 6 March 2019).

The Verkhovna Rada of Ukraine (2019), The Law of Ukraine “On Social Services”, available at: https://zakon.rada.gov.ua/laws/show/2671-19?lang=en (Accessed 6 March 2019).

Verkhovod, I. S. (2007), "Economic mechanisms of employment of disabled people”, Ekonomika: problemy teorii ta praktyky, issue 222, vol. 4, pp. 829-835.

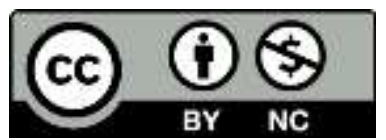

Цей твір ліцензовано на умовах Ліцензії Creative Commons «/з Зазначенням Авторства - Некомериійна 4.0 Міжнародна» (CC BY-NC 4.0). This is an open access journal and all published articles are licensed under a Creative Commons "Attribution-NonCommercial 4.0 International" (CC BY-NC 4.0). 